\title{
Cumulative effects of reduced tillage and mulching on soil properties under semi-arid conditions
}

\author{
W. Mupangwa ${ }^{\text {a,b,c,*, S. Twomlow }}{ }^{\text {d }}$, S. Walker ${ }^{\text {b }}$ \\ a ICRISAT, Matopos Research Station, P.O. Box 776, Bulawayo, Zimbabwe \\ ${ }^{\mathrm{b}}$ Department of Soil, Crop and Climate Sciences, University of Free State, P.O. Box 339, Bloemfontein 9300, South Africa \\ ${ }^{\mathrm{c}}$ CIMMYT, Southern Africa Regional Office, P.O. Box MP 163, Harare, Zimbabwe \\ ${ }^{\mathrm{d}}$ IFAD Regional Office, C/O UN Avenue, Nairobi, Kenya
}

\section{A R T I C L E I N F O}

\section{Article history:}

Received 11 January 2012

Received in revised form

26 October 2012

Accepted 9 November 2012

Available online 2 January 2013

\section{Keywords:}

Bulk density

Conservation agriculture

Hydraulic conductivity

Infiltration

Maize yield

Sorptivity

\begin{abstract}
A B S T R A C T
Declining soil productivity is one of the greatest challenges facing smallholder agriculture. This study assessed effects of reduced tillage and mulching on soil organic carbon, bulk density, infiltration and maize yield. Treatments consisted of three tillage methods (conventional ploughing, ripping and planting basins) combined factorially with mulch levels $\left(0,0.5,1,2,4,8\right.$ and $\left.10 \mathrm{t} \mathrm{ha}^{-1}\right)$. The experiment was run for four growing seasons allowing for a rotation of maize, cowpea and sorghum in some of the fields. A new experimental field was opened each year and maintained in subsequent seasons until the end of the experiment.

Soil organic carbon increased with time in all tillage systems and more SOC gained in planting basins. Soil bulk density decreased with time in all tillage systems irrespective of mulch quantity applied. Ripping loosened the soil much deeper than the other tillage methods. Total infiltration in all treatments was similar over the four seasons. Soil structural changes resulted in increased unsaturated hydraulic conductivity and sorptivity of the clay loam soil. Maize yield increased with time in all treatments. Long term studies need to be conducted to substantiate the results on soil property and crop yield improvements observed in the reported study.
\end{abstract}

(c) 2012 Elsevier Ltd. All rights reserved.

\section{Introduction}

Soil degradation is a serious challenge and an important environmental issue in many ecosystems of sub-Saharan Africa. Rainfed smallholder agro-ecosystems in sub-Saharan Africa are characterized by low productivity largely due to widespread soil degradation (Twomlow et al., 2006). The soils are generally infertile and the situation is exacerbated by the limited use of external nutrient inputs (Belane and Dakora, 2010; Cobo et al., 2009; Sanchez, 2002). Restoring and maintaining soil productivity remain a major challenge for smallholder agriculture in sub-Saharan Africa. Reducing soil tillage, mulching with crop residues and crop rotation/associations when applied simultaneously have the potential to halt and reverse some of the challenges the smallholder farmers are facing. Reduced tillage, mulching and crop rotation have the potential of reversing physical, chemical and biological degradation of soils

\footnotetext{
* Corresponding author. Current address: CIMMYT, Southern Africa Regional Office, PO Box MP163, Mount Pleasant, Harare. Tel.: +263 773930140.

E-mail addresses: mupangwa@yahoo.com,w.mupangwa@cgiar.org (W. Mupangwa).
}

(Arshad et al., 1999; Dexter, 2004) under different climatic conditions and soil types (Daraghmeh et al., 2009).

Positive changes have been observed in soil organic carbon content (Halvorson et al., 2002), physical properties such as bulk density and porosity (Arshad et al., 1999), and microbial activities (Salinas-Garcia et al., 1997). Significant changes in soil organic carbon (SOC), bulk density and infiltration have been recorded on smallholder farms and research stations where conservation agriculture practices have been implemented (Belder et al., 2007; Thierfelder and Wall, 2009, 2010). Mulching combined with reduced tillage is effective in reducing surface runoff, maintaining soil structure, conserving soil water and adding organic matter to the soil (Giller et al., 2009; Głab and Kulig, 2008; Liebig et al., 2004). The inclusion of legumes as part of a rotation can improve soil productivity through nitrogen fixation and non-nitrogen benefits such as soil water availability to cereals (Rao and Mathuva, 2000; Ncube et al., 2009).

While substantial information on crop yield benefits of CA practices has been generated, there is a dearth of information on the impact of the currently promoted conservation agriculture interventions on quality of different soil types (texture and structure) 
under semi-arid regions of southern Africa. In semi-arid cropping systems combining reduced tillage, mulching and crop rotation may have synergistic effects on the physical, chemical and biological properties of soil. The purpose of this paper is to show the effects of combining reduced tillage and mulching on soil properties over time under semi-arid conditions. In the study total soil organic carbon (SOC), bulk density and cumulative infiltration were measured from fields that had been exposed to CA practices for periods ranging from one to four growing seasons. Unsaturated hydraulic conductivity $\left[K\left(h_{0}\right)\right]$ and capillary sorptivity $\left[S\left(h_{0}\right)\right]$ were calculated from total infiltration data. In the last season of experimentation $(2007 / 08)$ maize (Zea mays L.) was grown in all four fields and grain yield results are presented in this paper to demonstrate the impact of improved soil conditions on crop productivity.

\section{Materials and methods}

\subsection{Description of experimental site and design}

The experiment was conducted at Matopos Research Station $\left(28^{\circ} 30^{\prime} \mathrm{E}, 20^{\circ} 23^{\prime} \mathrm{S}, 1344 \mathrm{~m}\right.$ above sea level) in southern Zimbabwe from 2004/05 to 2007/08 growing season. Matopos Research Station is lies in agro-ecological region 4 of Zimbabwe (Fig. 1) and the station is located $30 \mathrm{~km}$ south of Bulawayo. The soil at Matopos is a ChromicLeptic Cambisol derived from basaltic greenstone (Moyo, 2001) and its properties are summarized in Table 1 . Seasonal rainfall received during the period of experimentation varied between 359 and $832 \mathrm{~mm}$. The long term mean annual rainfall is $573 \mathrm{~mm}$ (Mupangwa et al., 2011) with the peak rainfall period stretching from December to February. The site experiences average minimum and maximum temperatures of 13 and $26^{\circ} \mathrm{C}$, with annual pan evapotranspiration ranging between 1600 and $2600 \mathrm{~mm}$ (FAO, 1998).

The experiment consisted of three tillage methods (animaldrawn conventional ploughing and tine ripping, and hand-dug planting basins) combined factorially with seven mulch levels $\left(0,0.5,1,2,4,8\right.$ and $\left.10 \mathrm{t} \mathrm{ha}^{-1}\right)$ on weight basis. The tillage
Table 1

Physical and chemical characteristics of the clay loam soil used for experimentation at Matopos Research Station, Zimbabwe.

\begin{tabular}{lcccc}
\hline Soil property & \multicolumn{4}{l}{ Soil depth $(\mathrm{cm})$} \\
\cline { 2 - 5 } & $0-6$ & $6-16$ & $16-40$ & $40-60$ \\
\hline Clay (\%) & 41 & 38 & 47 & 52 \\
Silt (\%) & 20 & 23 & 17 & 17 \\
Sand (\%) & 38 & 39 & 36 & 31 \\
pH $\left(\mathrm{CaCl}_{2}\right)$ & 7.5 & 7.6 & 7.7 & 7.8 \\
O.C. $(\%)$ & 0.46 & 0.80 & 0.37 & 0.48 \\
$\mathrm{Ca}\left(\mathrm{Cmol}_{\mathrm{c}} \mathrm{kg}^{-1}\right)$ & 40.2 & 40.9 & 32.3 & 33.4 \\
$\mathrm{Mg}\left(\mathrm{Cmol}_{\mathrm{c}} \mathrm{kg}^{-1}\right)$ & 14.8 & 15.4 & 16.6 & 19.7 \\
$\mathrm{~K}\left(\mathrm{Cmol}_{\mathrm{c}} \mathrm{kg}^{-1}\right)$ & 1.98 & 1.77 & 1.64 & 1.67 \\
\hline
\end{tabular}

method $\times$ mulch level combinations were arranged in a split-plot design with three replications in each experimental field. The main plot factor was tillage method $(63 \mathrm{~m} \times 6 \mathrm{~m}$ ) and seven mulch levels were randomly allocated in sub-plots $(8 \mathrm{~m} \times 6 \mathrm{~m})$ on each tillage treatment. In each experimental field tillage methods were randomized in each block and plots were separated by a $1 \mathrm{~m}$ pathway to avoid movement of residue from one plot to the next when tillage was undertaken. In each experimental field blocks were separated by a $2 \mathrm{~m}$ pathway and the four fields used in this study were separated by $10-15 \mathrm{~m}$ wide buffer. Digging of planting basins and donkey-drawn ripping were conducted in September/ October each year with mulch applied just after tillage operations. Planting basins were spaced at $0.9 \mathrm{~m} \times 0.6 \mathrm{~m}$ and each basin measured $0.15 \mathrm{~m}$ (length) $\times 0.15 \mathrm{~m}$ (width) $\times 0.15 \mathrm{~m}$ (depth). Riplines were spaced at $0.9 \mathrm{~m}$ inter-row and the ripping depth achieved with a single pass varied between 0.15 and $0.18 \mathrm{~m}$. Conventional ploughing was done after receiving effective planting rain $(30-50 \mathrm{~mm})$ in November/December and maize residue was applied as mulch after the tillage operation.

A new experimental field was opened each year and maintained in subsequent seasons until the end of the experiment in the 2007/ 08 growing season (Table 2 ). In each experiment field used between

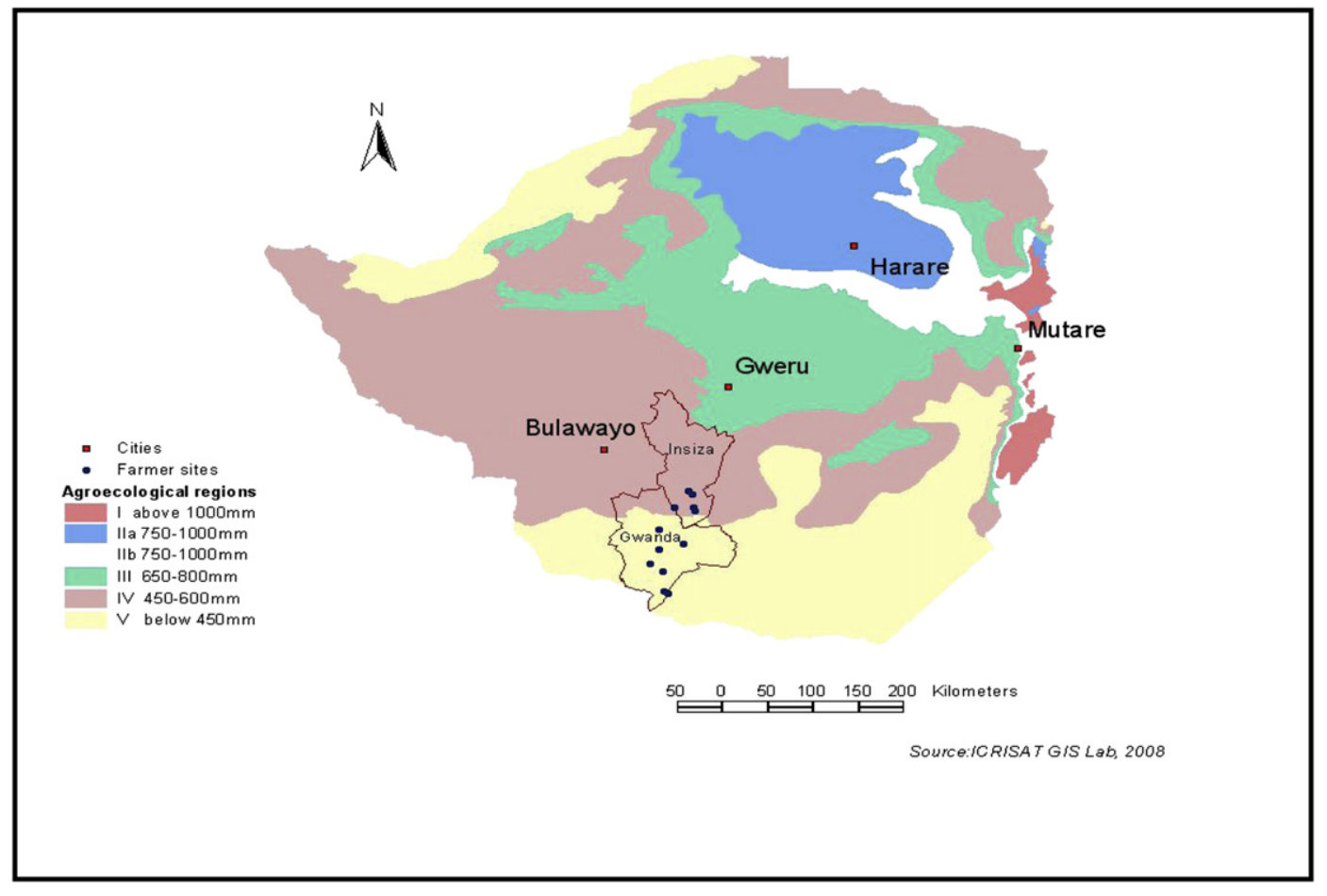

Fig. 1. Agro-ecological regions of Zimbabwe and the location of Matopos Research Station. Adapted from Mupangwa (2008). 
Table 2

Experimental fields used and crops grown in each field during the period of experimentation at Matopos Research Station, Zimbabwe.

\begin{tabular}{|c|c|c|c|}
\hline $\begin{array}{l}\text { Field } \\
\text { number }\end{array}$ & $\begin{array}{l}\text { Number of seasons } \\
\text { of experimentation }\end{array}$ & Season(s) field was used & Crop sequence \\
\hline 1 & 1 & $2007 / 08$ & Maize (M) \\
\hline 2 & 2 & $2006 / 07$ and $2007 / 08$ & Maize-Maize (MM) \\
\hline 3 & 3 & $2005 / 06,2006 / 07$ and $2007 / 08$ & Maize-Cowpea-Maize (MCM) \\
\hline 4 & 4 & $2004 / 05,2005 / 06,2006 / 07$ and $2007 / 08$ & Maize-Cowpea-Sorghum-Maize (MCSM) \\
\hline
\end{tabular}

2005 and 2008, the main and sub plot sizes were $63 \mathrm{~m} \times 6 \mathrm{~m}$ and $8 \mathrm{~m} \times 6 \mathrm{~m}$ respectively. At the beginning of each season every tillage $\times$ mulch treatment combination received a fresh application of maize residue mulch (with C:N ratio of 60 on average) in all experimental fields. In the first year of each experimental field, maize residue was imported from other fields in order to achieve the targeted mulch application rates. During winter all maize residues used for mulching in the next season were left in the fields because the experimental site was protected from livestock. Based on earlier work by Ncube et al. (2007) it was determined that a typical household in southern Zimbabwe would apply manure at $3 \mathrm{tha}^{-1}$ if available. Cattle manure ( $40 \%$ organic carbon, $0.43 \% \mathrm{~N}, 0.21 \% \mathrm{P}$ ) was therefore applied at $3 \mathrm{t} \mathrm{ha}^{-1}$ in October each year in all plots as basal soil fertility amendment in every experimental field. The cattle manure was placed in the planting basins in the basin tillage system, dribbled along the ripline in the ripper tillage system and broadcast in the conventional tillage system. Experimental plots were handhoe weeded in all fields and maize grown in 2007/08 season received $20 \mathrm{~kg} \mathrm{~N} \mathrm{ha}^{-1}$ as topdressing at six weeks after planting.

\subsection{Soil sampling and measurements}

Soil samples for total SOC and bulk density analysis were collected from 24 to 28 March 2008. Infiltration measurements were made from 31 March to 4 April 2008. The sampling locations in each tillage treatment were; along crop rows in conventional ploughing, between riplines, within riplines, between planting basins and within planting basin. Measurements of SOC, bulk density and cumulative infiltration were made from plots under 0 , 4 and $10 \mathrm{t} \mathrm{ha}^{-1}$ mulch cover in each field and tillage system.

Soil samples for total SOC analysis were collected from 0 to $0.10 \mathrm{~m}$ and 0.10 to $0.20 \mathrm{~m}$ depths using steel cores measuring $0.03 \mathrm{~m}$ internal diameter by $0.95 \mathrm{~m}$ length. Three sampling locations were used in each plot for each soil depth with two plots being sampled per treatment. A composite soil sample for each soil depth was made by mixing samples collected from the three sampling locations. A sub-sample from each treatment was taken to the laboratory for air drying. After air drying the soil was sieved through a $2 \mathrm{~mm}$ sieve before analysing for total organic carbon using the Sommer's method (Anderson and Ingram, 1993).

Undisturbed soil samples for bulk density analysis were collected from each tillage method $\times$ mulch treatment combination in all four fields using steel cores measuring $0.05 \mathrm{~m}$ diameter and $0.05 \mathrm{~m}$ height. Soil samples were collected in duplicates from each plot at $0.05-0.10,0.10-0.15,0.15-0.20,0.20-0.25$ and $0.25-$ $0.30 \mathrm{~m}$ depth intervals. The soil samples were oven dried at $105^{\circ} \mathrm{C}$ for $48 \mathrm{~h}$ before calculating bulk density at each soil depth as mass per unit volume using the procedure outlined by Anderson and Ingram (1993).

Before infiltration was measured, soil water content in the $0-$ $0.1 \mathrm{~m}$ soil layer of selected treatments was determined by the capacitance probe (Gopher ${ }^{\circledR}$ version 9.2). Cumulative infiltration measurements were conducted in March 2008 at the end of the fourth season of experimentation. A minidisk infiltrometer produced by Decagon Devices (2007) was used and infiltration runs were conducted in duplicate for each tillage $\times$ mulch treatment combination in each experimental field. The micro-topography of the surface was levelled with a spatula in order to ensure adequate horizontal contact between soil surface and the sintered steel base of the infiltrometer. Infiltration measurements were made at a constant supply head $\left(h_{0}\right)$ of $-20 \mathrm{~mm}$ as recommended for clay soils (Decagon Devices, 2007). A steady state flow was reached after 10-15 $\mathrm{min}$ in all treatments. Changes in water volume in the water reservoir of the infiltrometer were recorded at $30 \mathrm{~s}$ interval.

Infiltration results were used to derive $K\left(h_{0}\right)$ and $S\left(h_{0}\right)$ at 0,4 and $10 \mathrm{t} \mathrm{ha}^{-1}$ mulch levels in each tillage treatment using the following procedure proposed by Zhang (1997) and symbols used in calculating the two parameters are summarized in Table 3 . The van Genuchten parameters $(A, n, \alpha)$ for a clay loam soil were derived from Carsel and Parrish (1988).

$I=C_{1}\left(h_{0}\right)+C_{2}\left(h_{0}\right) \cdot \sqrt{ } t$

The $K\left(h_{0}\right)$ of the soil is computed from

$K\left(h_{0}\right)=C_{1}\left(h_{0}\right) / A$

The $A$ is computed from

$A=\left[\left(11.65\left(n^{\wedge 0.1}-1\right)\right) \exp \cdot\left[2.92(n-1) \dot{\alpha} h_{0}\right]\right] /\left(\dot{\alpha} r_{0}\right)^{\wedge 0.91}$

$C_{2}$ is computed from

$C_{2}\left(h_{0}\right)=\left(I-C_{1}\left(h_{0}\right) \cdot t\right) / \sqrt{ } t$

\subsection{Statistical analysis}

All data were assessed for normality before being subjected to analysis of variance (ANOVA) using Genstat version 9. For total SOC content, tillage method, mulch quantity applied and number of seasons of experimentation were used as factors in the unbalanced design in ANOVA. An unbalanced treatment design in ANOVA was selected for analysis of soil properties because in the ripper and basin systems two sampling locations/positions were used while

Table 3

Symbols used in the equations for deriving $K$ and $S$ from infiltration data.

\begin{tabular}{ll}
\hline $\begin{array}{l}\text { Symbol used in } \\
\text { the equations }\end{array}$ & Full name \\
\hline$I$ & Total infiltration \\
$K$ & Unsaturated hydraulic conductivity \\
$S$ & Sorptivity \\
$C_{1}$ & Hydraulic conductivity coefficient \\
$C_{2}$ & Sorptivity coefficient \\
$t$ & Time \\
$A$ & van Genuchten parameter \\
$r_{0}$ & Radius of infiltrometer \\
$h_{0}$ & Hydraulic head \\
$n$ & van Genuchten parameter \\
$\alpha$ & van Genuchten parameter \\
\hline
\end{tabular}


one location/position in the conventional system was used. Tillage method, mulch quantity applied, soil depth and number of seasons of experimentation were used as factors in the analysis of bulk density. For cumulative infiltration, $K\left(h_{0}\right)$ and $S\left(h_{0}\right)$ data analysis tillage method, mulch quantity applied and number of seasons of experimentation were used as factors in an unbalanced design in ANOVA. The $K\left(h_{0}\right)$ data were positively skewed with a skewness coefficient of 3.33 and were therefore anti-log transformed before being subjected to analysis of variance (Webster, 2001). Maize yield data were analysed using split-plot ANOVA with number of seasons of experimentation as main plot, tillage method as sub plot and mulch applied as sub-sub plot factors. For each tillage system the linear regression model in Genstat (version 9) was applied to assess the relationship between observed maize grain yield and the number of seasons the experiment was run. Where the F-test indicated significant differences treatment means were compared using the Least Significant Differences (lsd) at $5 \%(P<0.05)$.

\section{Results and discussion}

\subsection{Total SOC}

Total SOC in the 0-0.2 m layer of the clay loam soil increased $(P=0.011)$ with time in all tillage systems tested (Fig. 2$)$. Regression analysis showed a significant $(P=0.039)$ increase in total SOC with time in all tillage systems. However, SOC was significantly $(P<0.001)$ higher in the planting basin compared to between basins and conventional tillage (Fig. 3). Changes in total SOC can be attributed to the cattle manure applied annually as basal soil fertility amendment before planting, the decomposing maize residues applied as mulch at the onset of each growing season and the cowpea stover which was left at the surface at harvest in 2005/06 and 2006/07 seasons (Mupangwa et al., 2012).

\subsection{Soil bulk density}

The tillage method $\times$ mulching $\times$ \#seasons under CA interaction had a significant $(P<0.032)$ effect on soil bulk density (Table 4$)$. On bare plots ( $0 \mathrm{t} \mathrm{ha}^{-1}$ mulch cover) the lowest bulk density was recorded along the ripline in the oldest field (Table 3 ). Under mulched conditions the lowest bulk density was recorded in the oldest field at all sampling positions in the three tillage systems tested. The decrease in bulk density with time was more apparent in the ripline and planting basin locations which had been

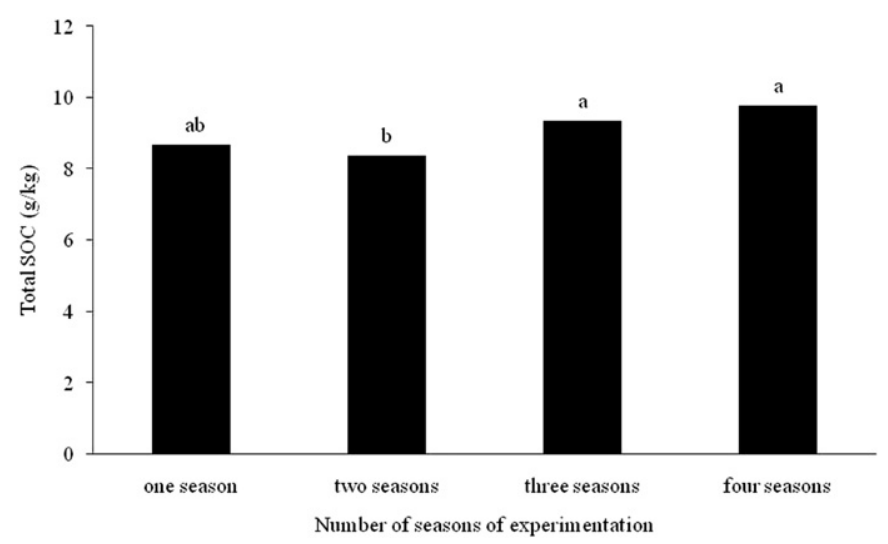

Fig. 2. Total SOC content $\left(\mathrm{g} \mathrm{kg}^{-1}\right)$ changes with time in the $0-0.2 \mathrm{~m}$ layer of a red clay loam soil at Matopos Research Station. Means followed by the same letter are not significantly different $(P<0.05)$.

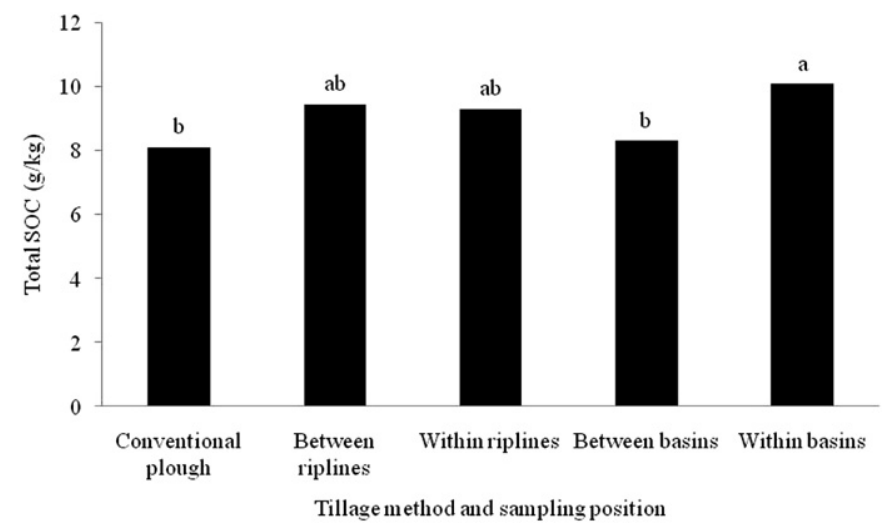

Fig. 3. Total SOC content $\left(\mathrm{g} \mathrm{kg}^{-1}\right)$ changes in the $0-0.2 \mathrm{~m}$ layer of a red clay loam soil under different tillage methods and sampling positions at Matopos Research Station. Means followed by the same letter are not significantly different $(P<0.05)$.

disturbed annually during tillage operations. The decrease in bulk density with the introduction of the ripper and basin systems is consistent with results from other different climatic regions and soil types (Belder et al., 2007; So et al., 2009). Low bulk density at BRL and BB locations under mulched conditions is an indication of in-situ structural changes of the clay loam soil. Generally the first year CA field (1 season) had lower bulk density than the field exposed to CA for two seasons because the youngest field had been fallow a season before it was incorporated into the experiment. In the oldest field (4 seasons) bulk density was lower at high mulch cover regardless of the tillage system used. Mulching could have reduced bulk density through promotion of aggregation and pore development in the soil system as the residues decomposed (Głab and Kulig, 2008; Hadas et al., 1994; Mulumba and Lal, 2008) and our results suggest that the clay loam soil at Matopos may require at least four years for this to happen.

\subsection{Cumulative infiltration}

All interactions of tillage method, mulch cover and number of seasons under CA practices had no significant influence on total infiltration. Total infiltration increased $(P<0.001)$ with time (Fig. 4$)$ and undisturbed (between riplines and between basins) sections of the ripper and basin systems had significantly lower total infiltration compared to the conventionally ploughed treatment. Generally the conventionally ploughed treatment had lower soil water content in the 0-0.1 m soil layer compared to the ripper and basin systems at the time infiltration measurements were taken (Table 5). Throughout 2007/08 cropping season the conventional system had the lowest soil water content compared to the other systems (Fig. 5). Also there could have been more water conducting pores in the conventional system despite soil disturbance during tillage operation. Mielke et al. (1984) and Moreno et al. (1997) report that water movement into and within the soil depends on available pore space and, the nature and alignment of pores relative to each other. Vauchin and Chopart (1997) observed higher capillary sorptivity and hydraulic conductivity of conventionally ploughed soil and attributed this to better pore connectivity in the plough layer. In the ripper tillage system the disturbed location (within riplines) had higher infiltration compared to the undisturbed (between riplines) location, a trend which is consistent with bulk density results (Table 4).

Our infiltration responses to tillage systems are in contrast to the results of Belder et al. (2007) and, Thierfelder and Wall (2010) who observed more total infiltration in conservation agriculture 
Table 4

Effect of mulching, reduced tillage and number of seasons of experimentation on soil bulk density $\left(\mathrm{g} \mathrm{cm}^{-3}\right)$ in the $0-0.30 \mathrm{~m} \mathrm{layer}$ of a clay loam soil ( $\left.n=2\right)$.

\begin{tabular}{|c|c|c|c|c|c|}
\hline \multirow[t]{2}{*}{ Mulch $\left(\mathrm{t} \mathrm{ha}^{-1}\right)$} & \multirow[t]{2}{*}{ Tillage and sampling location } & \multicolumn{4}{|c|}{ Number of seasons of experimentation } \\
\hline & & 1 & 2 & 3 & 4 \\
\hline \multirow[t]{6}{*}{0} & Conventional plough & 1.51 & 1.55 & 1.57 & 1.50 \\
\hline & Between ripline & 1.45 & 1.51 & 1.52 & 1.52 \\
\hline & Within riplines & 1.46 & 1.57 & 1.47 & 1.44 \\
\hline & Between basins & 1.63 & 1.55 & 1.48 & 1.50 \\
\hline & Within basins & 1.57 & 1.59 & 1.48 & 1.48 \\
\hline & Mean & 1.55 & 1.55 & 1.50 & 1.49 \\
\hline \multirow[t]{6}{*}{4} & Conventional plough & 1.51 & 1.62 & 1.54 & 1.48 \\
\hline & Between ripline & 1.48 & 1.54 & 1.54 & 1.45 \\
\hline & Within riplines & 1.48 & 1.53 & 1.45 & 1.43 \\
\hline & Between basins & 1.54 & 1.59 & 1.51 & 1.49 \\
\hline & Within basins & 1.44 & 1.55 & 1.50 & 1.46 \\
\hline & Mean & 1.49 & 1.57 & 1.51 & 1.46 \\
\hline \multirow[t]{6}{*}{10} & Conventional plough & 1.63 & 1.66 & 1.51 & 1.50 \\
\hline & Between ripline & 1.46 & 1.54 & 1.52 & 1.46 \\
\hline & Within riplines & 1.39 & 1.46 & 1.46 & 1.36 \\
\hline & Between basins & 1.55 & 1.62 & 1.49 & 1.47 \\
\hline & Within basins & 1.58 & 1.47 & 1.50 & 1.41 \\
\hline & Mean & 1.52 & 1.55 & 1.49 & 1.44 \\
\hline \multicolumn{2}{|c|}{$\operatorname{LSD}_{0.05}$ (tillage $\times$ mulch $\times$ number of seasons of experimentation) } & 0.096 & & & \\
\hline \multicolumn{2}{|l|}{$\mathrm{CV}(\%)$} & 7.2 & & & \\
\hline
\end{tabular}

systems (reduced tillage, mulching and crop rotation) compared to conventional tillage. The disparity of our results with previous findings can be attributed to a number of factors that include differences in soil type (texture and structure), time of the season measurements were taken, climatic conditions particularly rainfall patterns and tillage systems tested. The study by Belder et al. (2007) covered a wide range of soil textural classes found on smallholder farms of Zimbabwe. Soil type and climatic factors such as rainfall have a strong influence on topsoil structural properties (Mielke et al., 1984; So et al., 2009) which have a direct influence on infiltration. Thierfelder and Wall (2010) used the time to ponding method for estimating rainwater infiltration into soils exposed to conservation agriculture practices over varying periods.

\subsection{Unsaturated hydraulic conductivity and sorptivity}

The interaction of mulching, tillage system and number of seasons of experimentation significantly $(P<0.001)$ influenced $K\left(h_{0}\right)$ and $S\left(h_{0}\right)$ of the clay loam soil. $K\left(h_{0}\right)$ increased consistently with time under $4 \mathrm{t} \mathrm{ha}^{-1}$ mulch treatment in all tillage systems

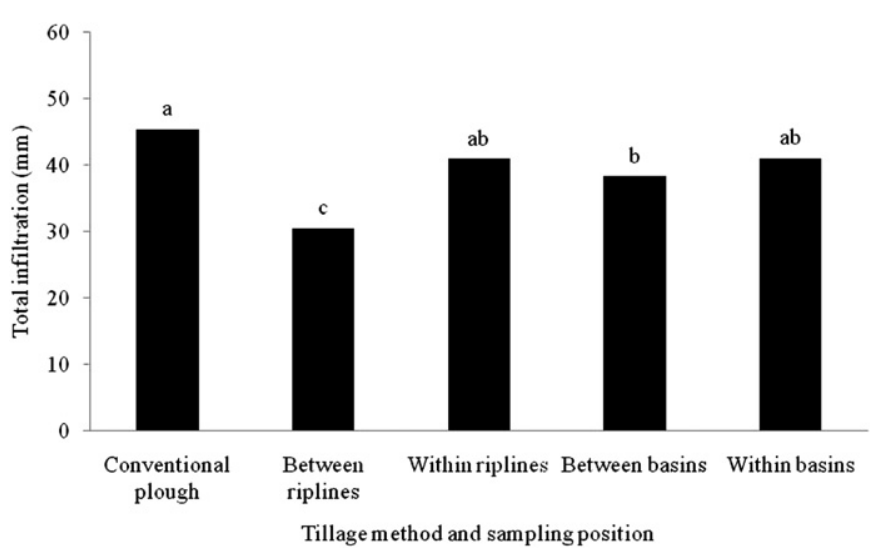

Fig. 4. Total infiltration for a clay loam soil in different tillage systems and sampling locations. Means followed by the same letter are not significantly different $(P<0.05)$.
(Table 6). At $4 \mathrm{t} \mathrm{ha}^{-1}$ mulch cover the soil in two, three and four seasons old fields had 1.1, 1.2 and 1.4 times higher $K\left(h_{0}\right)$ than the youngest field in the conventional system. In the RL location $K\left(h_{0}\right)$ was 1.7 times higher in two season old field, and 1.9 times more in the three and four year old fields compared to the youngest field at $4 \mathrm{t} \mathrm{ha}^{-1}$ mulch cover. In the basin system the within basin location had 1.2 and 1.3 times higher $K\left(h_{0}\right)$ in the three and four seasons old fields compared to the one season old field. In the undisturbed location of the basin system $K\left(h_{0}\right)$ was more than double in the three and four season fields compared to the youngest field. The observed changes in $K\left(h_{0}\right)$ can be attributed to soil structural improvements that were indicated by changes in soil bulk density (Table 4). Structural improvements could have led to the development of more water transmitting pores in the three fields under $4 \mathrm{t} \mathrm{ha}^{-1}$ mulch cover. A decrease in soil compaction, illustrated by bulk density results, brings about variations in pore geometry which can significantly influence water movement in the soil matrix (Das and Chopra, 1988). Lack of similar $K\left(h_{0}\right)$ trend under $10 \mathrm{tha}^{-1}$ mulch cover can be attributed to the results obtained from the three year old experimental field which had the lowest values of $K\left(h_{0}\right)$

Capillary $S\left(h_{0}\right)$ increased $(P<0.001)$ consistently with time at $4 \mathrm{t} \mathrm{ha}^{-1}$ mulch cover in conventional ploughing and within basin locations (Table 7), a trend which was consistent with $K\left(h_{0}\right)$ for the conventional and basin tillage systems (Table 6). High capillary $S\left(h_{0}\right)$ in the older fields can be an indication of more water conducting pores developing in the topsoil layer, being facilitated by increased SOC and reduced bulk density (Liepic et al., 2006; McGarry et al., 2000). In the ripper system the disturbed and undisturbed locations had similar $S\left(h_{0}\right)$ in bare plots. However, $S\left(h_{0}\right)$ doubled at $4 \mathrm{t} \mathrm{ha}^{-1}$ and was 1.5 times more at $10 \mathrm{tha}^{-1}$ mulch treatments in within ripline location compared to between riplines, a pattern which is in agreement with bulk density results. On the contrary the undisturbed between basins location had higher $S\left(h_{0}\right)$ than within basin at $4 \mathrm{t} \mathrm{ha}^{-1}$ mulch treatment in the basin tillage system, a trend which is consistent with the $K\left(h_{0}\right)$ results (Table 6). When averaged across seasons, unmulched soil had higher $S\left(h_{0}\right)$ compared to soil under mulched conditions. Drier soils have a higher $S\left(h_{0}\right)$ because of a greater gradient in matric potential compared to soils under mulched conditions (Azooz and Arshad, 1999; Bissett and O’Leary, 1996). 
Table 5

Volumetric water content (\%) measured by capacitance probe in 0-0.10 m soil layer before total infiltration measurements in March 2008 at Matopos Research Station.

\begin{tabular}{|c|c|c|c|c|c|}
\hline \multirow[t]{2}{*}{ Mulch (t ha $\left.{ }^{-1}\right)$} & \multirow[t]{2}{*}{ Tillage system } & \multicolumn{4}{|c|}{ Number of seasons of experimentation } \\
\hline & & 1 & 2 & 3 & 4 \\
\hline \multirow[t]{4}{*}{0} & Conventional plough & 10 & 9.8 & 7.7 & 8.2 \\
\hline & Within riplines & 9.4 & 18 & 13 & 11 \\
\hline & Within basins & 8.5 & 6.6 & 9.3 & 12 \\
\hline & Mean & 9.3 & 12 & 10 & 10 \\
\hline \multirow[t]{4}{*}{4} & Conventional plough & 13 & 13 & 11 & 6.5 \\
\hline & Within riplines & 7.3 & 15 & 14 & 16 \\
\hline & Within basins & 9.3 & 10 & 15 & 6.4 \\
\hline & Mean & 9.9 & 13 & 13 & 9.6 \\
\hline \multirow[t]{4}{*}{10} & Conventional plough & 11 & 10 & 6.1 & 8.2 \\
\hline & Within riplines & 11 & 7.6 & 11 & 12 \\
\hline & Within basins & 11 & 13 & 14 & 13 \\
\hline & Mean & 11 & 10 & 10 & 11 \\
\hline \multicolumn{2}{|c|}{$\mathrm{LSD}_{0.05}$ (tillage $\times$ mulch $\times$ number of seasons of experimentation) } & & 5.77 & & \\
\hline \multicolumn{2}{|c|}{$\mathrm{CV}(\%)$} & & 26.4 & & \\
\hline
\end{tabular}

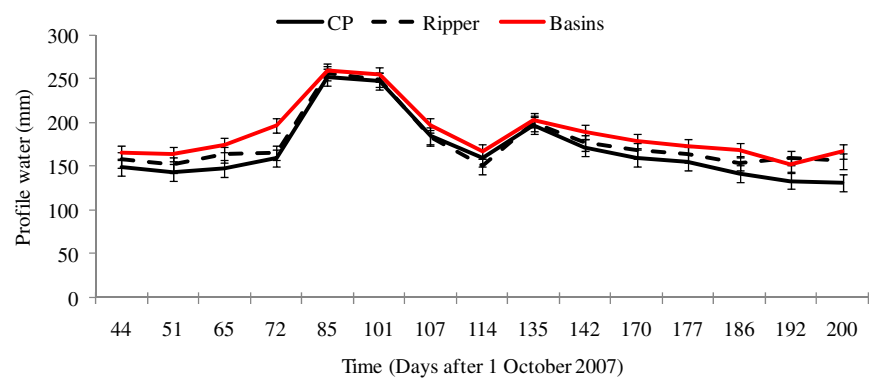

Fig. 5. Soil water changes in $0-0.6 \mathrm{~m}$ profile under conventional, ripper and basin (red line) systems across mulch levels during 2007/08 cropping period at MRS. Vertical bars indicate standard error of means $(n=3)$ ). (For interpretation of the references to colour in this figure legend, the reader is referred to the web version of this article.) Adapted from Mupangwa (2008).

\subsection{Maize grain yield}

The three-way interaction had no significant $(P=0.801)$ influence on grain production during the $2007 / 08$ season. The tillage system $\times$ number of seasons of experimentation interaction had a significant $(P<0.001)$ effect on maize grain yield. The oldest field (four seasons of experimentation) had significantly higher $(P<0.001)$ grain yield than the three younger fields (Fig. 6). Differences in maize grain yield between the oldest field and the three younger fields were greater in the basin system compared to the conventional and ripper tillage systems. The oldest field had 2.6, 2.2 and 1.2 times more grain than the first, second and third season fields in the conventional system. Regression analysis indicated a significant linear relationship $\left(P<0.001 ; r^{2}=0.46\right.$; s.e. $=750 \mathrm{~kg} / \mathrm{ha}$ ) between grain yield and the number of seasons the experiment was conducted in the conventional system. In the ripper system, the oldest field had 2.3, 2.5 and 1.4 times more grain compared to the first, second and third season fields. A significant linear relationship $\left(P<0.001 ; r^{2}=0.56\right.$; s.e. $\left.=559 \mathrm{~kg} / \mathrm{ha}\right)$ existed between grain yield and the number of seasons the experiment was conducted in the ripper system. A similar trend was observed in the basin system where the oldest field had 4.5, 3.4 and 2.1 times more grain than the first, second and third season fields. A linear relationship $\left(P<0.001 ; r^{2}=0.68 ;\right.$ s.e. $\left.=731 \mathrm{~kg} / \mathrm{ha}\right)$ between grain yield and the number of seasons the experiment was conducted also existed in the basin system. The lower $(P=0.280)$ grain yield in basins compared to ripper and the conventional systems is

Table 6

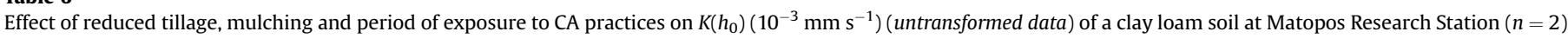

\begin{tabular}{|c|c|c|c|c|c|}
\hline \multirow[t]{2}{*}{ Mulch $\left(\mathrm{t} \mathrm{ha}^{-1}\right)$} & \multirow[t]{2}{*}{ Tillage and sampling location } & \multicolumn{4}{|c|}{ Number of seasons of experimentation } \\
\hline & & 1 & 2 & 3 & 4 \\
\hline \multirow[t]{6}{*}{0} & Conventional plough & 9.80 & 3.43 & 5.00 & 2.57 \\
\hline & Between ripline & 3.00 & 1.98 & 4.05 & 3.27 \\
\hline & Within riplines & 4.02 & 2.00 & 7.59 & 3.36 \\
\hline & Between basins & 3.77 & 2.32 & 3.93 & 1.59 \\
\hline & Within basins & 6.23 & 2.02 & 6.98 & 2.07 \\
\hline & Mean & 5.36 & 2.35 & 5.51 & 2.57 \\
\hline \multirow[t]{6}{*}{4} & Conventional plough & 3.46 & 3.66 & 4.00 & 4.84 \\
\hline & Between ripline & 2.95 & 2.78 & 2.93 & 2.93 \\
\hline & Within riplines & 1.59 & 2.68 & 3.09 & 3.09 \\
\hline & Between basins & 1.80 & 1.68 & 4.00 & 6.18 \\
\hline & Within basins & 3.02 & 3.00 & 3.48 & 4.02 \\
\hline & Mean & 2.56 & 2.76 & 3.50 & 4.21 \\
\hline \multirow[t]{6}{*}{10} & Conventional plough & 3.89 & 4.98 & 2.42 & 4.50 \\
\hline & Between ripline & 1.27 & 0.98 & 0.71 & 3.57 \\
\hline & Within riplines & 4.32 & 2.00 & 2.68 & 3.96 \\
\hline & Between basins & 1.61 & 4.64 & 0.80 & 4.52 \\
\hline & Within basins & 2.14 & 2.91 & 1.72 & 4.11 \\
\hline & Mean & 2.65 & 3.10 & 1.67 & 4.13 \\
\hline \multicolumn{2}{|c|}{ LSD $_{0.05}$ (tillage $\times$ mulch $\times$ number of seasons of experimentation) } & \multirow{2}{*}{\multicolumn{4}{|c|}{$\begin{array}{l}7.9 \times 10^{-4} \\
45\end{array}$}} \\
\hline \multicolumn{2}{|c|}{$\mathrm{CV}(\%)$} & & & & \\
\hline
\end{tabular}


Table 7

Effect of reduced tillage, mulching and number of seasons of experimentation on $S\left(h_{0}\right)(\mathrm{mm} / \sqrt{ } \mathrm{s})$ of a clay loam soil at Matopos Research Station ( $\left.n=2\right)$.

\begin{tabular}{|c|c|c|c|c|c|}
\hline \multirow[t]{2}{*}{ Mulch $\left(\mathrm{t} \mathrm{ha}^{-1}\right)$} & \multirow[t]{2}{*}{ Tillage and sampling location } & \multicolumn{4}{|c|}{ Number of seasons of experimentation } \\
\hline & & 1 & 2 & 3 & 4 \\
\hline \multirow[t]{6}{*}{0} & Conventional plough & 1.31 & 0.73 & 1.36 & 0.56 \\
\hline & Between ripline & 0.78 & 0.60 & 1.39 & 0.84 \\
\hline & Within riplines & 0.43 & 0.93 & 1.31 & 0.95 \\
\hline & Between basins & 0.65 & 0.97 & 0.91 & 0.84 \\
\hline & Within basins & 1.13 & 1.10 & 0.64 & 1.06 \\
\hline & Mean & 0.86 & 0.87 & 1.12 & 0.85 \\
\hline \multirow[t]{6}{*}{4} & Conventional plough & 0.52 & 0.84 & 1.39 & 0.92 \\
\hline & Between ripline & 0.23 & 0.51 & 0.43 & 0.67 \\
\hline & Within riplines & 0.40 & 1.26 & 1.13 & 0.73 \\
\hline & Between basins & 0.40 & 1.07 & 1.07 & 0.78 \\
\hline & Within basins & 0.37 & 0.71 & 0.79 & 0.96 \\
\hline & Mean & 0.38 & 0.88 & 0.96 & 0.81 \\
\hline \multirow[t]{6}{*}{10} & Conventional plough & 0.59 & 0.49 & 0.74 & 1.09 \\
\hline & Between ripline & 0.57 & 0.43 & 0.51 & 0.84 \\
\hline & Within riplines & 0.68 & 0.85 & 1.45 & 0.62 \\
\hline & Between basins & 0.50 & 0.93 & 0.82 & 1.01 \\
\hline & Within basins & 0.48 & 0.65 & 0.42 & 1.10 \\
\hline & Mean & 0.56 & 0.67 & 0.79 & 0.93 \\
\hline \multicolumn{2}{|c|}{ LSD $_{0.05}$ (tillage $\times$ mulch $\times$ number of seasons of experimentation) } & 0.257 & & & \\
\hline \multicolumn{2}{|l|}{$\mathrm{CV}(\%)$} & 34 & & & \\
\hline
\end{tabular}

attributed to waterlogging that was experienced between December and January during the 2007/08 growing season in the three younger experimental fields.

The higher maize productivity in the field used for four seasons can be attributed to the improved soil conditions reflected by the increases in SOC as a result of decomposing maize residues and cattle manure applied annually, a decrease in bulk density, and improved soil hydraulic properties. Improvements in SOC indicate an increase in SOM which is a source of plant nutrients and also promotes a proliferation of microbes involved in nutrient cycling in the soil. Reduced soil bulk density allows plant roots to explore the soil deeper for nutrients and water. Growth of plant roots into deeper soil layers can buffer crops against mid-season dry spells as roots are able to extract water from layers that are not significantly affected by soil evaporation during the growing season. Improved soil hydraulic properties promote the recharging of soil profile through increased infiltration during rainfall events and the subsequent storage of soil water for crops. Similar studies conducted over more than four cropping seasons under the same environmental conditions are critical in order to establish the long term effect of the conventional and reduced tillage treatments on

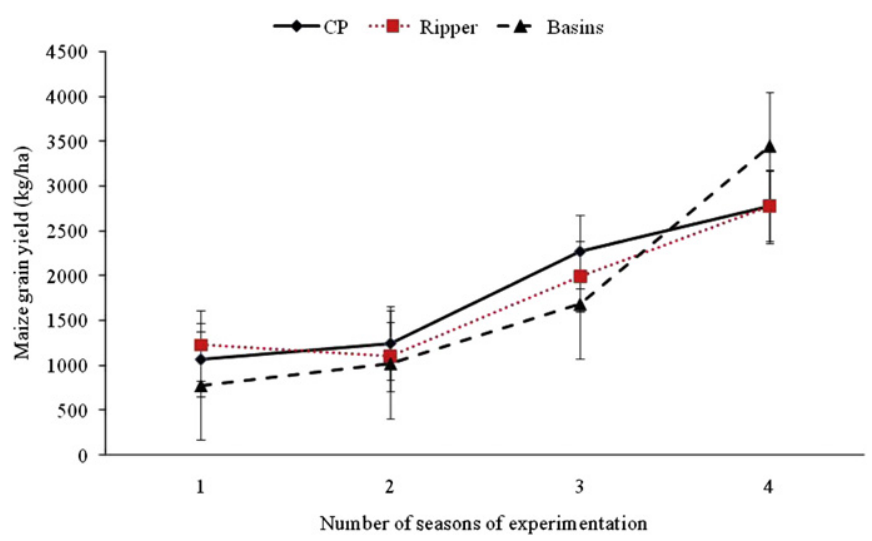

Fig. 6. Maize yield changes in conventional, ripper and basin tillage systems during the four seasons of experimentation on a red clay loam soil. Vertical bars represent standard error of means $(n=3)$. (For interpretation of the references to colour in this figure legend, the reader is referred to the web version of this article.)
SOC patterns. Long term studies will also highlight the quantity of crop residue mulch that can bring about significant changes in soil physical and chemical properties under dry conditions.

\section{Conclusion}

Total SOC increased with time in all tillage treatments even in a well managed conventional system that received annual application of cattle manure and maize residues. More total SOC was gained in the planting basin (WB) position over the four seasons and this is attributed to the annual spot application of cattle manure at $3 \mathrm{t} \mathrm{ha}^{-1}$. Soil fertility can therefore build up faster in the planting basin (WB) thereby increasing soil productivity. The lowest soil bulk density was recorded in the field that had been used for four seasons and generally the disturbed sections of ripper and basin systems had lower bulk density than the undisturbed locations. The conventional system had similar total infiltration with the disturbed sections of the ripper and basin systems. Unsaturated hydraulic conductivity and sorptivity of the clay loam soil only increased with time under $4 \mathrm{t} \mathrm{ha}^{-1}$ mulch cover in all tillage systems tested. Improvements in total SOC content, bulk density and hydraulic properties resulted in increased maize productivity with time. Despite the challenges of waterlogging experienced in seasons with above average rainfall, the basin tillage system showed a greater potential for improving crop productivity with time. Minimum tillage and mulching practices can offer an opportunity for sustainable management of smallholder agroecosystems of sub-Saharan Africa as soil conditions are improved and crop yields increased.

\section{Acknowledgement}

The authors wish to thank WaterNet for funding this research through the Challenge Program Project 17 "Integrated Water Resource Management for Improved Rural Livelihoods: Managing risk, mitigating drought and improving water productivity in the water scarce Limpopo Basin", funded through the CGIAR Challenge Program on Water and Food. We are also grateful to the ICRISAT field (Getrude Mpofu, Beckimpilo Ncube and Thulani Ndlovu) and laboratory (Murairo Madzvamuse, Jethro Ndlovu and Mthokozisi Moyo) staff for assisting in data collection and soil analysis. 


\section{References}

Anderson, J.M., Ingram, J.S.I., 1993. Tropical Soil Biology and Fertility. a Handbook of Methods, second ed. C.A.B. International, Wallingford, UK.

Arshad, M.A., Franzluebbers, A.J., Azooz, R.H., 1999. Components of surface soil structure under conventional and no-tillage in northwestern Canada. Soil and Tillage Research 53, 41-47.

Azooz, R.H., Arshad, M.A., 1999. Soil infiltration and hydraulic conductivity under long-term no-tillage and conventional tillage systems. Canadian Journal of Soil Science 76, 143-152.

Belane, A.K., Dakora, F.D., 2010. Symbiotic N2 fixation in 30 field grown cowpea (Vigna unguiculata (L.) Walp.) genotypes in the upper West region of Ghana measured using ${ }^{15} \mathrm{~N}$ natural balance. Biology and Fertility of Soils 46, 191198.

Belder, P., Twomlow, S., Hove, L., 2007. Early Evidence of Improved Soil Quality with Conservation Farming Under Smallholder Farming Conditions in Zimbabwe. Paper Presented at the ICID Conference, November 2007, Johannesburg, South Africa.

Bissett, M.J., O’Leary, G.J., 1996. Effects of conservation tillage and rotation on water infiltration in two soils in south-eastern Australia. Australian Journal of Soil Research 34, 299-308.

Carsel, R.F., Parrish, R.S., 1988. Developing joint probability distributions of soil water retention characteristics. Water Resources Research 24, 755-769.

Cobo, J.G., Dercon, G., Monje, C., Mahembe, P., Gotosa, T., Nyamangara, J. Delve, R.J., Cadisch, G., 2009. Cropping strategies, soil fertility investment and land management practices by smallholder farmers in communal and resettlement areas in Zimbabwe. Land Degradation and Development 20, 492-508.

Daraghmeh, O.A., Jensen, J.R., Petersen, C.T., 2009. Soil structure stability under conventional and reduced tillage in a sandy loam. Geoderma 150, 64-71.

Das, D.K., Chopra, U.K., 1988. Soil water movement, balance and its use by crops as influenced by soil physical conditions. In: Somani, L.L. (Ed.), Soil Physical Conditions and Crop Growth, Monograph. Geo-Environ Academia and Divyajyoti Prakashan, Shastri Nagar, India, pp. 231-254.

Decagon Devices, 2007. Minidisk Infiltrometer. User's Manual, Version 4.

Dexter, A.R., 2004. Soil physical quality. Part 1. Theory, effects of soil texture, density and organic matter, and effects on root growth. Geoderma 120, 201-214.

FAO, 1998. World Reference Base for Soil Resources. World Soil Resources Report 84, Rome.

Giller, K.E., Witter, E., Corbeels, M., Tittonell, P., 2009. Conservation agriculture and smallholder farming in Africa: the heretic's view. Field Crops Research 114, $23-$ 34.

Głab, T., Kulig, B., 2008. Effect of mulch and tillage system on soil porosity under wheat (Triticum aestivum). Soil and Tillage Research 99, 169-178.

Hadas, A., Rawitz, E., Etkin, H., Margolin, M., 1994. Short-term variations of soil physical properties as a function of the amount of $\mathrm{C} / \mathrm{N}$ ratio of decomposing cotton residues. I. Soil aggregation and aggregate tensile strength. Soil and Tillage Research 32, 183-198.

Halvorson, A.D., Wienhold, B.J., Black, A.L., 2002. Tillage, nitrogen, and cropping system effects on soil carbon sequestration. Soil Science Society of America Journal 66, 906-912.

Liebig, M.A., Tanaka, D.L., Wienhold, B.J., 2004. Tillage and cropping effects on soil quality indicators in the Northern Great Plains. Soil and Tillage Research 78 , 131-141.

Liepic, J., Kus, J., Nosalewicz, A., Turski, M., 2006. Tillage system effects on stability and sorptivity of soil aggregates. International Agrophysics 20, 189-193.
McGarry, D., Bridge, B.J., Radford, B.J., 2000. Contrasting soil physical properties after zero and traditional tillage of an alluvial soil in the semi-arid subtropics. Soil and Tillage Research 53, 105-115.

Mielke, L.N., Wilhelm, W.W., Richards, K.A., Fenster, C.R., 1984. Soil physical characteristics of reduced tillage in a wheat-fallow system. Transaction ASAE 84 , 1724-1728.

Moreno, F., Pelegrh, F., Fernindez, J.E., Murillo, J.M., 1997. Soil physical properties, water depletion and crop development under traditional and conservation tillage in southern Spain. Soil and Tillage Research 41, 25-42.

Moyo, M., 2001. Representative Soil Profiles of ICRISAT Research Sites. Soils Report NoA666. AREX, Chemistry and Soil Research Institute, Harare, Zimbabwe.

Mulumba, L.N., Lal, R., 2008. Mulching effects on selected soil physical properties. Soil and Tillage Research 98, 106-111.

Mupangwa, W., Walker, S., Twomlow, S., 2011. Start, end and dry spells of the growing season in semi-arid southern Zimbabwe. Journal of Arid Environments 75, 1097-1104

Mupangwa, W., Twomlow, S., Walker, S., 2012. Reduced tillage, mulching and rotational effects on maize (Zea mays L.), cowpea (Vigna unguiculata (Walp) L.) and sorghum (Sorghum bicolor L. (Moench)) yields under semi-arid conditions. Field Crops Research 132, 139-148.

Mupangwa, W., 2008. Water and Nitrogen Management for Risk Mitigation in Smallholder Cropping Systems. Unpublished PhD thesis, University of the Free State, South Africa.

Ncube, B., Twomlow, S., van Wijk, M.T., Dimes, J.P., Giller, K.E., 2007. Productivity and residual benefits of grain legumes to sorghum under semi-arid conditions in south-western Zimbabwe. Plant and Soil 299, 1-15.

Ncube, B., Dimes, J.P., van Wijk, M.T., Twomlow, S.J., Giller, K.E., 2009. Productivity and residual benefits of grain legumes to sorghum under semi-arid conditions in south-western Zimbabwe: unravelling the effects of water and nitrogen using simulation modelling. Field Crops Research 110, 173-184.

Rao, M.R., Mathuva, M.N., 2000. Legumes for improving maize yields and income in semi-arid Kenya. Agriculture, Ecosystem and Environment 78, 123-137.

Salinas-Garcia, J.R., Hons, F.M., Matocha, J.E., Zuberer, D.A., 1997. Soil carbon and nitrogen dynamics as affected by long-term tillage and nitrogen fertilization. Biology and Fertility of Soils 25, 182-188.

Sanchez, P., 2002. Soil fertility and hunger in Africa. Science 225, 2019-2020.

So, H.B., Grabski, A., Desborough, P., 2009. The impact of 14 years of conventional and no-till cultivation on the physical properties and crop yields of a loam soil at Grafton NSW, Australia. Soil and Tillage Research 104, 180-184.

Thierfelder, C., Wall, P., 2009. Effects of conservation agriculture techniques on infiltration and soil water content in Zambia and Zimbabwe. Soil and Tillage Research 105, 217-227.

Thierfelder, C., Wall, P., 2010. Rotation in conservation agriculture systems of Zambia: effects on soil quality and water relations. Journal of Experimental Agriculture 46 (3), 1-17.

Twomlow, S.J., Steyn, J.T., du Preez, C.C., 2006. Dryland farming in southern Africa. In: Petersen, G.A., Unger, W.P., Payne, W.A. (Eds.), Dryland Agriculture, second ed.Agronomy Monograph No. 23 American Society of Agronomy, Madison, Wisconsin, pp. 769-836 (Chapter 19).

Vauchin, M., Chopart, J.L., 1997. Multi-disc infiltrometry for in-situ determination of the surface hydrodynamic features of a gravel soil in Cote-d'Ivoire. L'Agronomie Tropicale 46 (4), 259-271.

Webster, R., 2001. Statistics to support soil research and their presentation. European Journal of Soil Science 52, 331-340.

Zhang, R., 1997. Determination of soil sorptivity and hydraulic conductivity from the minidisk infiltrometer. Soil Science Society of America Journal 61, 1024-1030. 